\title{
Improvement of Productivity by Stand-support Sintering in Commercial Sintering Machines
}

\author{
Ken-ichi HIGUCHI, Takuya KAWAGUCHI, ${ }^{1)}$ Masanori KOBAYASHI, ${ }^{2)}$ Yohzoh HOSOTANI, \\ Keiichi NAKAMURA, ${ }^{1)}$ Koichi IWAMOTO ${ }^{31}$ and Masami FUJIMOTO ${ }^{4)}$
}

Steel Research Laboratories, Nippon Steel Corporation, Shintomi, Futtsu, Chiba 293-8511 Japan.

1) Kimitsu Works, Nippon Steel Corporation Kimitsu, Kimitsu ,Chiba 299-1141 Japan.

2) Plant Engineering \& Technology Center, Nippon Steel Corporation Shintomi, Futtsu, Chiba 293-8511 Japan.

3) Formerly Plant Engineering \& Technology Center, Nippon Steel Corporation, now at Nittetsu Plant Designing Corporation Shintomi, Futtsu, Chiba 293-8511 Japan. 4) Formerly Process Technology Research Laboratories, Nippon Steel Corporation, now at Krosaki Corporation Higashihama, Yawatanishi, Kitakyushu, Fukuoka 806-0002 Japan.

(Received on June 2, 2000; accepted in final form on September 13, 2000)

The sinter cake load on the combustion-melting zone has a great effect on structure formation of sinter cake especially at the lower layer. It increases the permeability resistance of sintering bed due to gas channel plugging and also affects the qualities of the sinter products indirectly.

A new sintering technique, called "Stand-support sintering", for supporting the sinter cake with bars or plates attached to pallets has been developed.

As a result of a pot test, it was found that the stand-support sintering sharply shortened the sintering time. Further, productivity was improved by nearly $20 \%$. This technique was applied to the sintering machines at Kimitsu works. Nearly homogenous sinter cake support was obtained when the stands were properly arranged in pallets to make shrinkage and gas flow rate of sintering bed constant in the width and strand directions at the commercial plant. As a result of an operation test with the low stands and the high stands, it was found that the improvement of productivity of the high stands was larger than that of the low stands. Product yield and SI did not decrease even though FFS increased. Stands started to support the sinter cake load just after the melt near the top of the stands solidified. Shrinkage stopped and gas flow rate increased when the stands started to support the sinter cake load. Porosity above $5 \mathrm{~mm}$ in sinter cake with stands was larger than that in sinter cake without stands in the lower part of the bed. An increase in the unsintered portion was not seen near the stands. Sinter products with stands were porous and had good reducibility.

KEY WORDS: agglomeration; sinter; iron ore; sinter cake; permeability; productivity; product yield; cold strength; reducibility; pore structure.

\section{Introduction}

The gas flow rate along the sintering strand under constant suction pressure depends on gas flow resistance in the sintering bed. The moisture condensation from the upper layer of the sintering bed to the lower layer causes the increase of gas flow resistance at the ignition furnace. ${ }^{1-3)}$ Many techniques have been developed to improve the permeability of the moisture condensation zone. ${ }^{4,5)}$

On the other hand, the combustion-melting zone is enlarged with the progress of sintering and gas flow resistance in the bed is increased, which in turn also retards the sintering speed. ${ }^{2,6)}$ As a cause of the permeability resistance increase in the combustion-melting zone, gas volume expansion by heating and gas channel plugging by formation of calciumferrite melt and silicate melt had been considered. ${ }^{2)}$ The former is fundamentally clear and it is possible to assume the extent of the resistance theoretically, but as for the latter, the details have not been known because of the diffi- culty of analyzing the combustion-melting zone structure.

Compressive force due to gravity was thought to have a great effect on structure formation of sinter cake, especially at the lower layer. ${ }^{7)}$ Inazumi et al. have directed their attention to the effect of the sinter cake load upon the combustion-melting zone on the permeability and have already developed a "Magnetically-levitated sintering" levitating sinter cake by magnetic force. ${ }^{8)}$ Further the effect of the sinter cake load on permeability through the structural changes of stem pores formed during the sintering reactions was studied with the use of CT (computerized tomography) analytical technique. ${ }^{9}$

In this paper we introduce a new sintering technology, called "Stand-support sintering", in which the sinter cake is supported with bars or plates attached to pallets.

This technique has been applied practically to the sintering machines in Kimitsu works and, as a result, productivity was improved. 


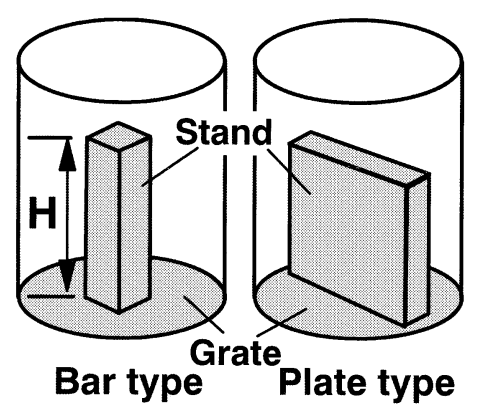

Fig. 1. Schematic diagram of apparatus used in pot test.

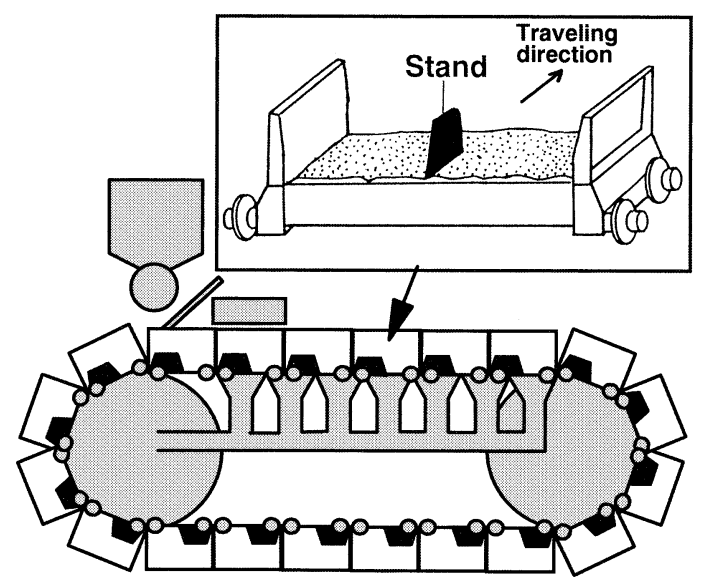

Fig. 2. Schematic diagram of test pallets used in stand-support sintering at a commercial plant.

\section{Experimental Method}

Pot tests using stands were carried out. Practical raw mixtures were used for sintering in a $300 \mathrm{~mm}$ diameter pot under a constant suction pressure of $19.6 \mathrm{kPa}$. Figure 1 shows stands for supporting the sinter cake constructed by erecting steel bars or steel plates on the pot grate. The height of the sintering bed was $750 \mathrm{~mm}$ and the height of the stands was set at three levels of 200, 400 and $600 \mathrm{~mm}$. For comparison with the stand-support sintering, the raw mixture was sintered under an additional load. High hydraulic load $(0.15 \mathrm{MPa})$ was applied to the surface of the sintering bed to clarify the effect of load on sintering.

Figure 2 shows an example of stands set on a pallet grate in the operation test at a commercial sintering machine.

Before the long-term commercial operation test, some pallets were exchanged to the pallets with stands in the commercial plant for a pre-installation test. ${ }^{10)}$ In this test, we confirmed that there was no problem in sintering operation and discharge behavior of sinter cake with stand-support sintering. Two types of stands were used in the operation test to determine a desirable stand height. In this paper, we call the two types of stands "the high stands" whose height is above half of the bed height and "the low stands" whose height is below half of the bed height respectively. In the conventional operation, the bed height is between 500 and $600 \mathrm{~mm}$.

The shrinkage of the sintering bed was measured directly at five points in the width direction of a pallet using a tense wire put between sidewalls. The gas flow rate on the surface of the sintering bed was measured at three points in the
Table 1. Results of pot tests.

\begin{tabular}{|c|c|c|c|c|}
\hline & $\begin{array}{l}\text { Sintering } \\
\text { time(min) }\end{array}$ & $\begin{array}{c}\text { Shrinkage } \\
(\mathrm{mm})\end{array}$ & \begin{tabular}{|l|} 
Product \\
yield(\%)
\end{tabular} & $\begin{array}{l}\text { Productivity } \\
\left(\mathbf{t} /\left(\mathbf{d} \cdot \mathbf{m}^{2}\right)\right)\end{array}$ \\
\hline With additional load & 46.9 & 130 & 81.5 & 35.7 \\
\hline Base & 39.7 & 99 & 82.1 & 41.9 \\
\hline \multicolumn{5}{|l|}{ With stand } \\
\hline Bar $\mathrm{H}=200 \mathrm{~mm}$ & 37.6 & 80 & 83.0 & 44.4 \\
\hline Bar $\mathrm{H}=400 \mathrm{~mm}$ & 33.4 & 58 & 80.9 & 49.6 \\
\hline Bar $\mathrm{H}=600 \mathrm{~mm}$ & 34.1 & 34 & 82.0 & 47.4 \\
\hline Plate $\mathrm{H}=200 \mathrm{~mm}$ & 36.9 & 73 & 81.2 & 43.7 \\
\hline Plate $\mathrm{H}=400 \mathrm{~mm}$ & 31.7 & 50 & 81.8 & 50.6 \\
\hline Plate $\mathrm{H}=600 \mathrm{~mm}$ & 32.4 & 23 & 80.3 & 48.5 \\
\hline
\end{tabular}

width direction of the pallet. The temperature and composition of exhaust gas under the pallet were also measured. In addition, sinter cakes with and without stands were sampled after sintering and evaluated by a CT analytical technique. ${ }^{9)}$ JIS-RI and porosity of the sinter product were also measured.

\section{Experimental Results}

\subsection{Pot Test Results}

Table 1 shows the results of pot tests. The stand-support sintering sharply shortened the sintering time. The sintering time reduction by a $200 \mathrm{~mm}$ height stand was smaller than that by other stands. The sintering time increased inversely when hydraulic pressure was applied to the surface of the sintering bed. The product yield did not change greatly in any test. Productivity, a combined index of sintering time and product yield in a pot test, was improved by nearly $20 \%$.

The sintering time closely corresponded to shrinkage of the sintering bed. This means that void fraction of the sintering bed has a great effect on permeability. Sato et al. ${ }^{11)}$ showed two factors in shrinkage, a melt volume as a function of a melting ratio of raw material and fluidity of melt as a function of the chemical composition of sinter. Cumming et al. ${ }^{12)}$ distinguished two types of shrinkage in the sintering process, that at a micro and that at a macro level. They called macro shrinkage of the sintering bed "slump" and showed that a main factor in slump was the flow of liquid melt.

In this study, it is clearly shown that the load on the combustion-melting zone is also a major factor in shrinkage.

\subsection{Stand Designing for Commercial Plant}

Before the installation of stands in a commercial plant, some tests for designing the stand arrangement in the pallet, stand materials and stand shapes were carried out.

Figure 3 shows the results of the measurement of the shrinkage of a sintering bed in various arrangements of stands. Two portions of sinter cake, one is above the stand (P1) and the other is between stand and side wall (P2) or between two stands (P3), were measured. In a normal operation condition without stands, total shrinkage of sintering bed was about $100 \mathrm{~mm}$ when the initial height of sintering bed was $550 \mathrm{~mm}$.

A small value of height differences of sinter cakes between the two portions $(\Delta H)$ means that stands support sinter cake homogeneously because the height of sinter cake indicates porosity of sinter cake directly.

The height difference of sinter cakes increased as a distance between stands increased both in the width direction 


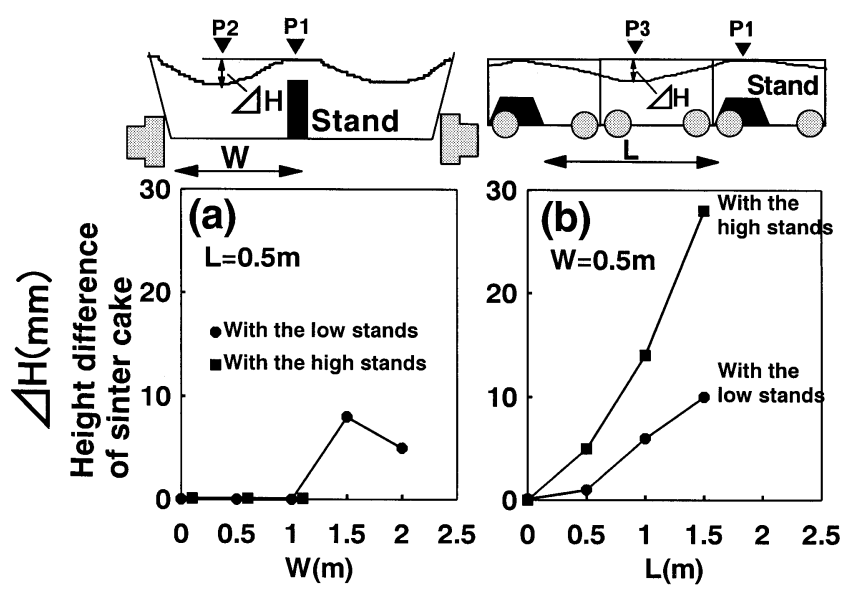

Fig. 3. Changes in shrinkage of sintering bed in accordance with distance between stands in width direction of pallet (a) and along strand direction (b)

(a)
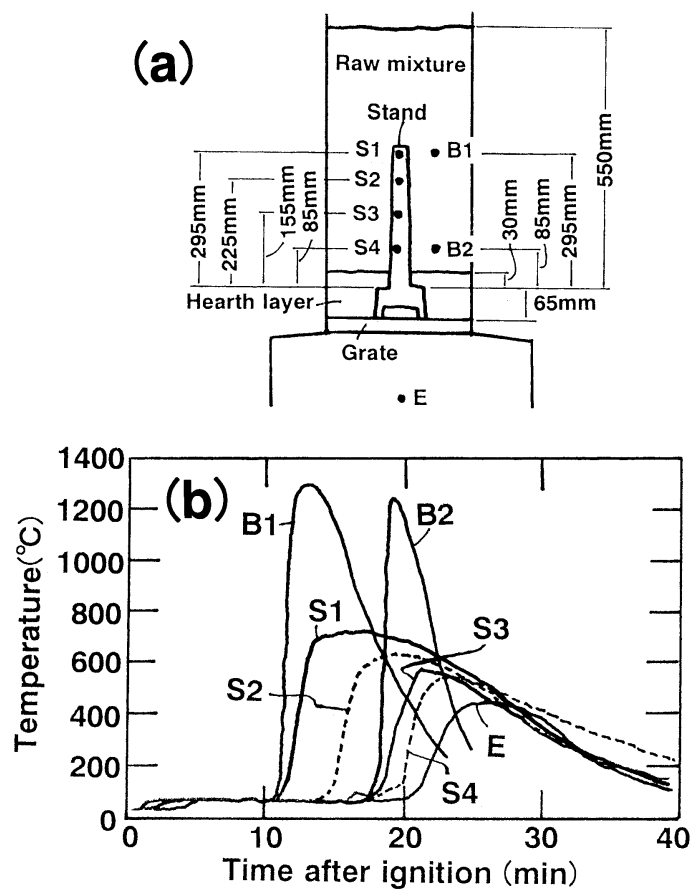

Fig. 4. Measurement position (a) and result (b) of stand temperature (S1-S4: Stand temperature, B1-B2: Bed temperature, E: Exhaust gas temperature).

of the pallet (Fig. 3(a)) and along the strand direction (Fig. 3(b)). This indicates that sinter cake does not behave as a complete solid material. However, nearly homogenous shrinkage, which height differences over all sinter cake were within $10 \mathrm{~mm}$, was obtained by a proper arrangement of the stands. The gas flow rate of the sintering bed was also homogenous when the stands were properly arranged.

For smooth discharging of sinter cake after sintering, stands were arranged in the backside of a pallet along the strand direction (Fig. 2).

Stand Material was also examined. Figure 4 shows the pot test results of the measurement of the temperature of the high stand during sintering. When the flame front reached the upper part $(\mathrm{S} 1)$ of the stand $(13.7 \mathrm{~min}$ after ignition), the temperature of the upper part of the stand started to increase and rose to $700^{\circ} \mathrm{C}$. On the other hand, the temperature of the lower part (S4) of the stand remained

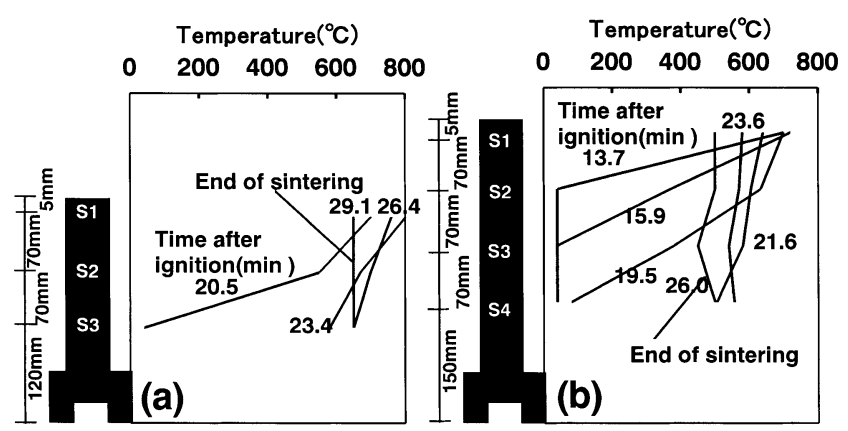

Fig. 5. Comparison between the heat propagation of the low stand (a) and that of the high stand (b).

Table 2. Stand materials used in durability test.

\begin{tabular}{|l|l|c|c|}
\hline & \multicolumn{1}{|c|}{ Matrix } & $\begin{array}{l}\text { Mean crack } \\
\text { length } \\
(\mathrm{mm})\end{array}$ & $\begin{array}{l}\text { Strength at high } \\
\text { temperature } \\
(\mathrm{MPa})\end{array}$ \\
\hline A & Ferrite - pearlite & 0.00 & 20 \\
\hline B & Ferrite - pearlite & 0.02 & 50 \\
\hline C & Austenite & 0.10 & 110 \\
\hline D & Austenite & 0.25 & 120 \\
\hline E & Austenite - ferrite & 0.05 & 75 \\
\hline
\end{tabular}
* After rapid heating to $900{ }^{\circ} \mathrm{C}$ and quenching 100 times
* Creep strength at $700{ }^{\circ} \mathrm{C}$ for $1000 \mathrm{hr}$

low at that time.

The temperature of the lower part (S4) of the stand increased gradually about 8 minutes after the temperature of the upper part (S1) of the stand started to increase. Afterwards, the temperature of whole of the stand became the same.

This indicates that the high stands are exposed to a severe thermal condition in which the temperature difference in the same material is about $700^{\circ} \mathrm{C}$ and remains thereat for $8 \mathrm{~min}$, the same being repeated over 20 times in a day.

Figure 5 shows a comparison between the heat propagation of low stands after ignition and that of the high stands. The temperature difference of the low stand was also $700^{\circ} \mathrm{C}$ when the temperature of the upper part (S1) of the stand started to increase at $20.5 \mathrm{~min}$ after ignition. At $23.4 \mathrm{~min}$ after ignition, the temperature of whole of the stand became the almost same level. This result concludes that the thermal condition of the low stand is less severe than that of the high stand.

Therefore it is necessary to use a material for the stand with not only strength at high temperature but also resistance to thermal shock. Stands made from various materials as shown in Table 2 were attached to pallets of a commercial plant in a durability test. As a result, material B having not only strength at high temperature but also resistance to thermal shock was chosen as the stand material.

Concerning the shape of the stands, the plate type stands were chosen to ensure the sinter cake support in the commercial plant whose amount of sinter cake was much larger than that of a pot test. In addition, trapezoidal stands were chosen based on the results of a FEM (Finite element method) analysis showing that the maximum stress of the upper side of the stand during sintering decreased as length of the upper side of the stand was shortened.

The height of trapezoidal stands $300 \mathrm{~mm}$ in height made from material B decreased by only $50 \mathrm{~mm}$, without any serious cracks being generated, after a two-year durability test. 
Table 3. Operation results of stand-support sintering in Kimitsu No. 1 sintering machine.

\begin{tabular}{|l|c|c|c|}
\hline & Base & $\begin{array}{l}\text { With the } \\
\text { low stands }\end{array}$ & $\begin{array}{l}\text { With the } \\
\text { high stands }\end{array}$ \\
\hline Productivity $\left(\mathbf{t} /\left(\mathbf{d} \cdot \mathbf{m}^{2}\right)\right)$ & 40.0 & 41.2 & 41.6 \\
\hline FFS $(\mathrm{mm} / \mathrm{min})$ & 31.3 & 33.8 & 36.9 \\
\hline Product yield $(\%)$ & 85.5 & 85.3 & 84.8 \\
\hline Burnt lime ratio(\%) & 1.40 & 1.91 & 1.25 \\
\hline SI (\%) & 88.5 & 88.2 & 88.3 \\
\hline
\end{tabular}

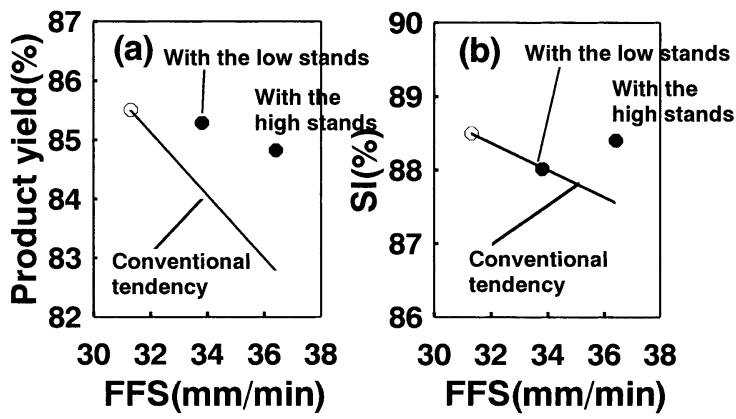

Fig. 6. Changes in product yield (a) and SI (b) after stand installation.

\subsection{Operation Test Results}

Table 3 shows the operation results regarding Kimitsu No. 1 sintering machine whose sintering area is $183 \mathrm{~m}^{2}$. To determine the desirable height of stands, the low stands were installed in the sintering machine first, and then the high stands were substituted for the low stands gradually. FFS (Flame front speed) was improved by installation of both the low stands and the high stands, respectively. On the other hand, the product yield and strength of sinter were almost constant. As a result, productivity was increased even though burnt lime consumption decreased gradually. The improvement ratio of the productivity of the high stands was larger than that of the low stands. The feature of the stand-support sintering was that product yield and SI (Shatter index) did not decrease even though FFS increased, as shown in Fig. 6. This fact is possibly due to homogenous sintering of the lower part of the sintering bed. As a result of this operation test, it was clearly shown that the high stands were preferable to the low stands. Accordingly, installation of the high stands in a larger sintering machine was tested. Figure 7 shows the operation results regarding Kimitsu No. 3 sintering machine whose sintering area is $500 \mathrm{~m}^{2}$. After installation of the high stands was completed, productivity increased by $10 \%$ and product yield and SI were almost constant.

\section{Discussion}

\subsection{Mechanism of Sinter Cake Support}

Figure 8 shows the results of the measurement of the heat propagation of the sintering bed and the load applied to a stand during a sintering pot test.

The temperature of the sintering bed near the top of the stand was measured by a thermocouple, and the load applied to the stand was measured by the load cell under the stand. The load, which corresponds to suction pressure, was applied to the stand after ignition. The load did not change even when the temperature rose rapidly and the front of the combustion-melting zone reached the top of the stand.

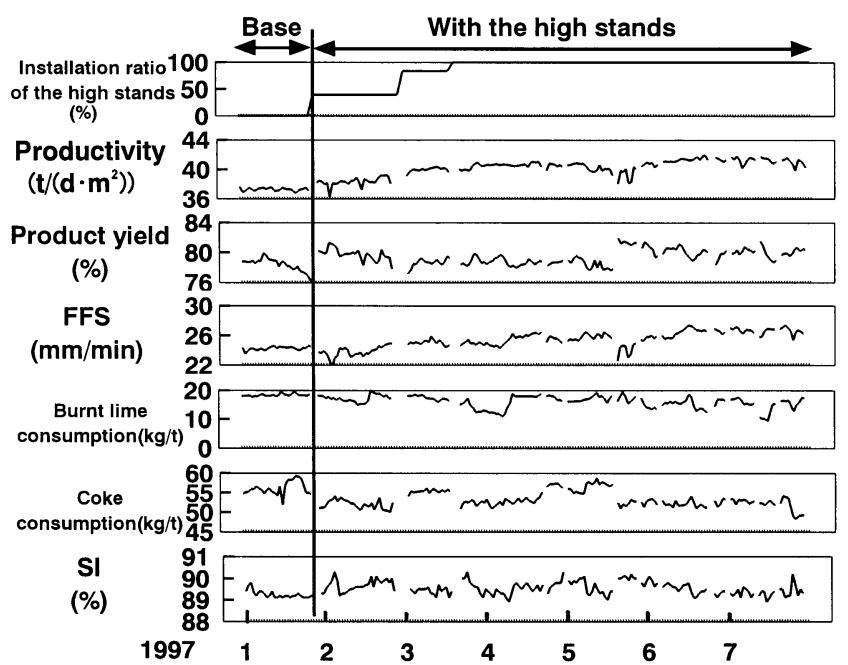

Fig. 7. Operation results of stand-support sintering in Kimitsu No. 3 sintering machine.
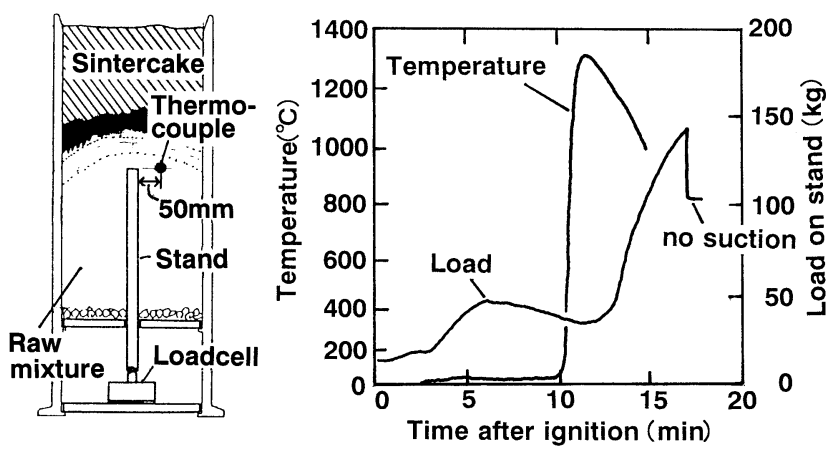

Fig. 8. Results of measurement of load on stand during sintering.

Afterwards, the load started to increase when the temperature near the top of the stand decreased to $1200^{\circ} \mathrm{C}$. The load on the stand increased in accordance with the progress of sintering.

The above indicates that the stand starts to support the sinter cake load just after the melt near the top of stand solidifies, and that the stand continues to support the sinter cake load until the end of sintering.

\subsection{Factors in Increased Productivity in Plant Op- eration}

Productivity of the sintering process in plant operation is expressed as follows.

$$
P=60 \cdot 24 / 1000 \cdot \mathrm{FFS} \cdot \rho \cdot \eta_{1} \cdot \eta_{2}
$$

$P \quad:$ Productivity $\left(\mathrm{t} /\left(\mathrm{d} \cdot \mathrm{m}^{2}\right)\right)$

FFS : Flame front speed $(\mathrm{mm} / \mathrm{min})$

$\rho \quad$ : Bulk density of raw mixture bed $\left(\mathrm{t} / \mathrm{m}^{3}\right)$

$\eta_{1} \quad$ : Sinter cake yield (\%)

$\eta_{2}$ : Product yield (\%)

Table 4 shows an analysis of factors in increased productivity as determined in the operation test conducted with regard to Kimitsu No. 3 sintering machine. The results of this test showed that an improvement of FFS is the main cause for the improvement of productivity.

In addition, other factors also contribute to the improvement of productivity. 
Table 4. Changes in productivity factors of Kimistu No. 3 sintering machine.

\begin{tabular}{|l|l|l|c|}
\hline & Base & $\begin{array}{l}\text { With the } \\
\text { high stands }\end{array}$ & $\begin{array}{l}\text { Increase } \\
\text { ratio }(\%)\end{array}$ \\
\hline Productivity $\left(\mathbf{t} /\left(\mathbf{d} \cdot \mathbf{m}^{2}\right)\right)$ & 37.3 & 40.8 & 9.4 \\
\hline FFS $(\mathbf{m m} / \mathbf{m i n})$ & 24.2 & 25.9 & 6.9 \\
\hline Bulk density $\left(\mathrm{t} / \mathbf{m}^{3}\right)$ & 1.61 & $1.66^{*}$ & 3.2 \\
\hline Sinter cake yield $\eta 1(\%)$ & 88.3 & 88.0 & -0.3 \\
\hline Product yield $\eta_{2}(\%)$ & 78.4 & 79.4 & 1.3 \\
\hline
\end{tabular}

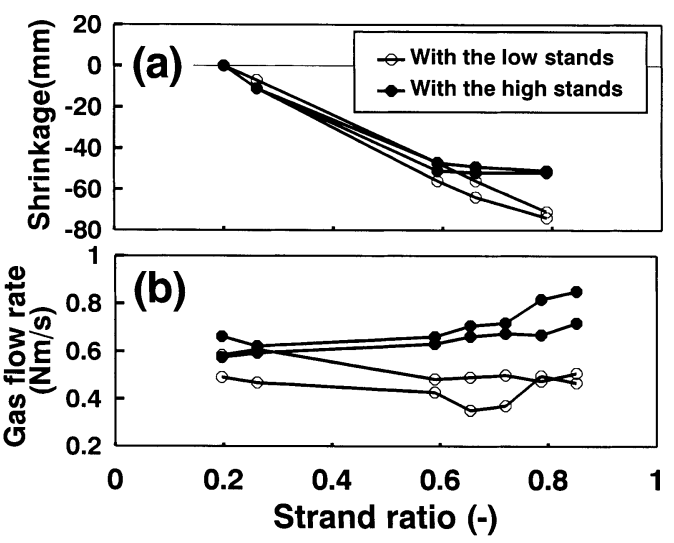

Fig. 9. Changes in shrinkage (a) and gas flow rate (b) by stand in Kimitsu No. 1 sintering machine.

Pallet volume decreases by $0.9 \%$ upon a stand being installed. But bulk density increased even before correction of the pallet volume, which increase was due to the increase of the bed height.

In a conventional operation, suction pressure increased due to an increase in the total permeability resistance of the sintering bed when the bed height was increased. However, bed permeability was improved enough to allow a high bed height in the stand operation. Moreover, product yield was increased due to homogenous sintering of the lower part of the sintering bed, even though the sintering speed increased.

\subsection{Factors for Determining Desirable Height of Stands}

Figure 9 shows a comparison of the shrinkage and gas flow rate on the surface of the sintering bed in the case of the low stands with those in the case of the high stands.

The sintering bed of the pallet in which the low stands were installed shrunk linearly as the sintering progressed. On the other hand, the sintering bed of the pallet in which the high stands were installed did not shrink from the part of the latter half of the strand. Though there was no difference between the gas flow rate of the low stands and that of the high stands in the former half of the strand, the gas flow rate of the high stands increased remarkably in the latter half of the strand.

The place along the strand where shrinkage stopped and the gas flow rate increased corresponded to the point where the upper surface of the combustion-melting zone (Flame behind) reached the top of the high stands. Therefore, it was thought that the sinter cake load started to be supported at this point and sintering after this point was done under a small load condition. Figure $\mathbf{1 0}$ shows the results of the measurement of the temperature and the oxygen content of exhaust gas under a pallet during sintering. In this measure-

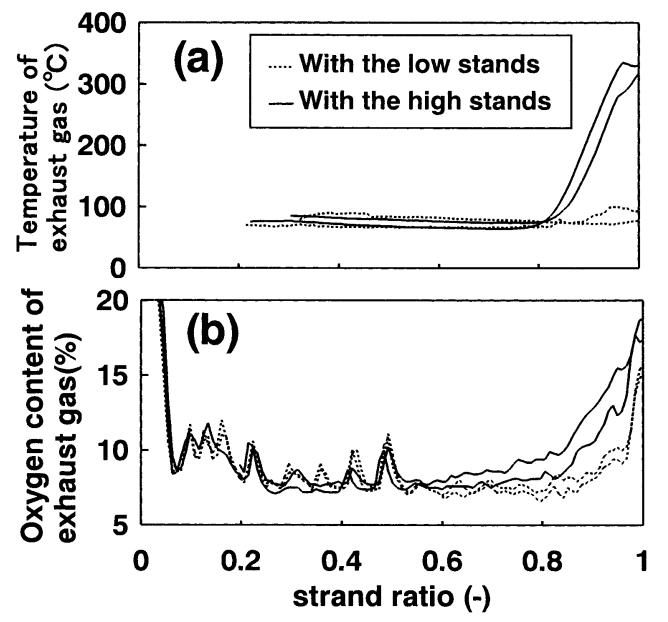

Fig. 10. Changes in temperature (a) and oxygen content (b) of exhaust gas in Kimitsu No. 1 sintering machine.

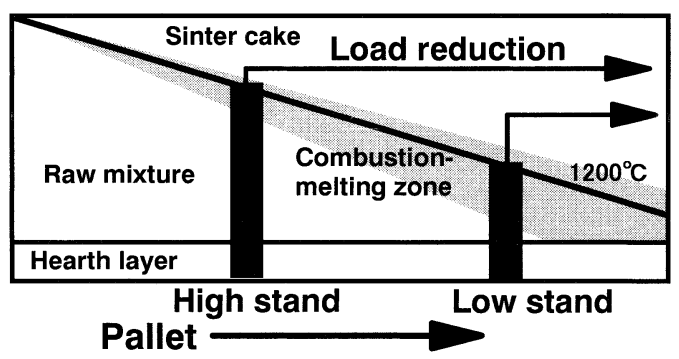

Fig. 11. Changes in improvement zone in accordance with height of stand.

ment the strand speed was kept constant. The point at which the temperature and the oxygen content of the exhaust gas rose in the case of the high stands was earlier than that at which those rose in the case of the low stands. This indicates that the sintering process with the high stands was progressed faster than with the low stands.

Figure 11 shows the relation between the stand height and improvement zone that would be sintered under a small load. Because the upper surface of the combustion-melting zone reaches the top of the high stands earlier than that of the low stands, the amount of raw mixture that would be sintered under a small load is increased. On the other hand, the combustion-melting zone is enlarged when the low stands start to support the sinter cake load, and the amount of raw mixture that would be sintered under a small load is decreased. Therefore, the high stands have much a larger effect than the low stands. However, extremely high stands pierce through sinter cake. ${ }^{10)}$

\subsection{Improvement of Pore Structure of Sinter Cake}

Figure 12 shows an example of CT images of sinter cake in the width direction of the pallet made in plant tests. The sinter cake with the high stands was more porous than that without stands in the lower part. An increase in the un-sintered portion was not seen near the high stand while many un-sintered portions were seen near the stand in pot tests. ${ }^{13)}$ This is probably because the heat loss of stands at the commercial plant was relatively smaller than that of the pot test.

Figure 13 shows the results of a quantitative evaluation of the pore structure of the sinter cake. Porosity in the sinter 


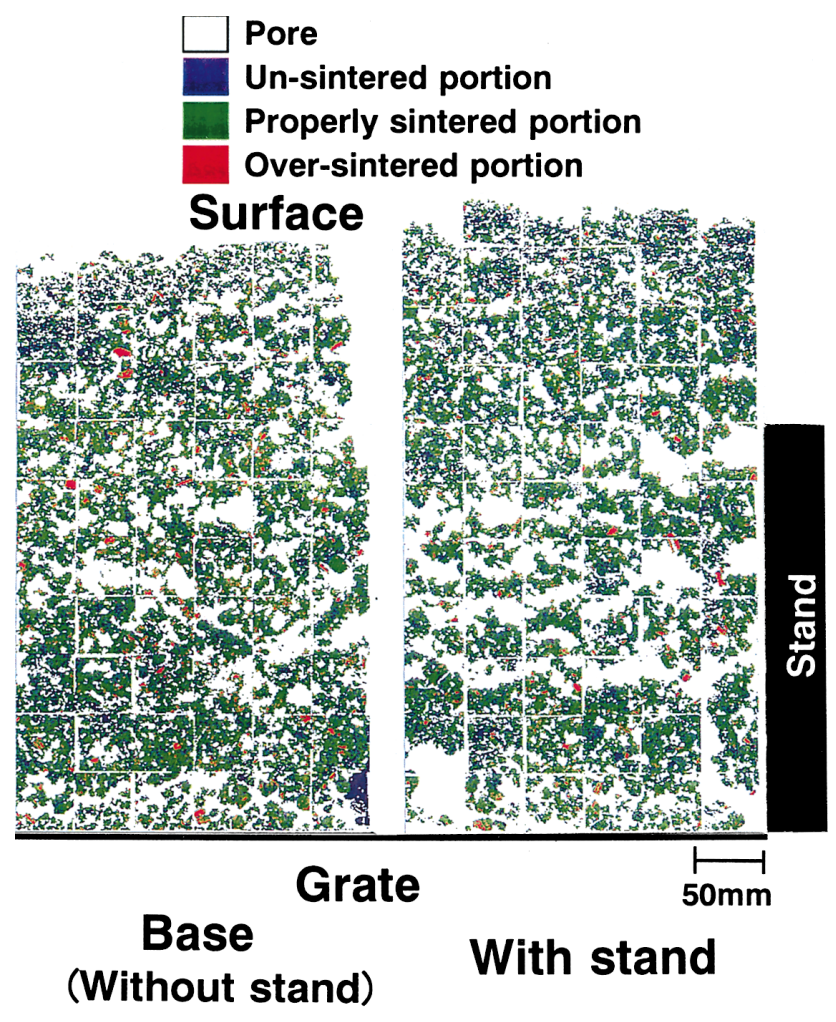

Fig. 12. CT images of vertical section of sinter cake with and without stand.

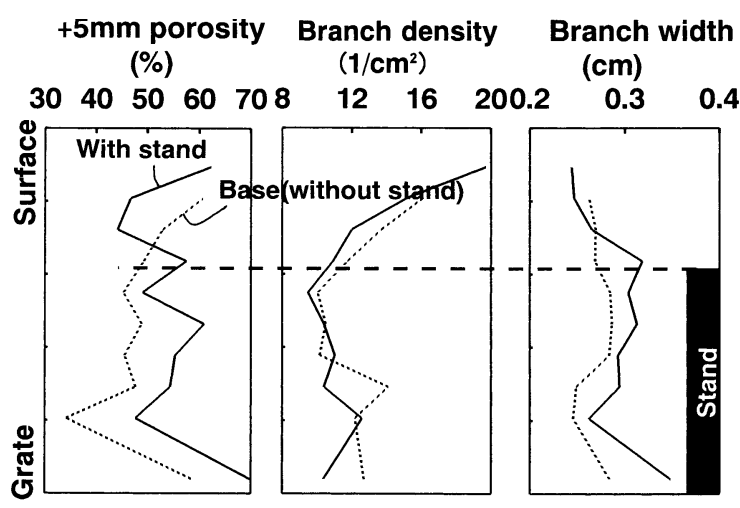

Fig. 13. Pore structures of sinter cake with and without stand.

cake above $5 \mathrm{~mm}$ with the high stands was larger than that in the sinter cake without stands in the lower part. This indicates that an open pore of sinter cake was well developed by sinter cake support. Moreover, the width of the branch of the sinter cake with the stands increased while the branch density did not change.

Nushiro et al $^{14)}$ showed the effect of the load on structure change in the moisture condensation zone.

From this result, it is considered that the effect of the load on the structure change in the combustion-melting zone would be much larger than the effect on the structure change in the moisture condensation zone mentioned above because the combustion-melting zone is more mobile than the moisture condensation zone due to the presence of melt.

\subsection{Changes in Quality of Sinter Products}

Figure 14 shows the distribution of JIS-RI and porosity of sinter products in the height direction of the sintering bed. Porosity was measured by an image analysis. JIS-RI in

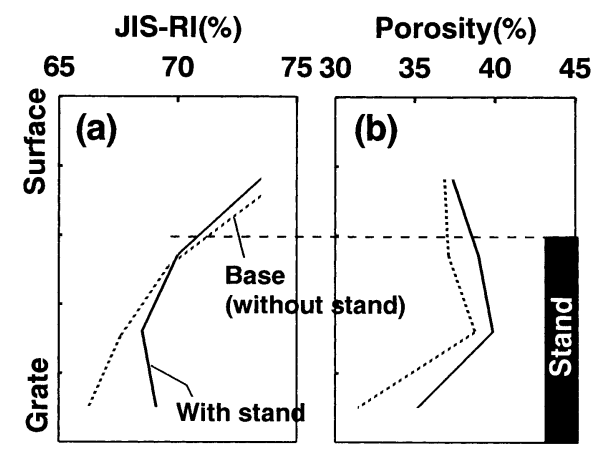

Fig. 14. JIS-RI (a) and porosity (b) of sinter products with and without stand.

the lower part was improved in the case of sinter products with the stand.

Upon a microscopic observation being made, it was determined that stand sinters had complex creeks and many pores. This is thought to be because of the increase in sinter cake porosity due to the sinter cake being supported and the delay in gathering of pores during sintering due to the sintering time being shortened. These factors are thought to be the main causes for the improvement of reducibility.

\section{Conclusions}

"Stand-support sintering", that is, supporting the sinter cake with bars or plates attached to pallets, has been developed and applied practically to the sintering machines in Kimitsu works.

(1) Shrinkage of the sintering bed has a great effect on permeability. The load on the combustion-melting zone is the major factor in shrinkage.

(2) Sinter cake did not behave as a complete solid material. However, nearly homogenous shrinkage was obtained as a result of stands being properly arranged in pallets. Trapezoidal stands made from material having both strength at high temperature and resistance to thermal shock were chosen to bear the severe thermal condition.

(3) Improvement ratio of productivity of the high stands (above $250 \mathrm{~mm}$ ) was larger than that of the low stands (below $250 \mathrm{~mm}$ ). Product yield and SI did not decrease even though FFS increased.

(4) Stands started to support the sinter cake load just after the melt near the top of the stands solidifies. Further, stands continued to support the sinter cake load until the end of sintering.

(5) Porosity above $5 \mathrm{~mm}$ in sinter cake with the stands was larger than that without the stands in the lower part. Porosity of sinter products with the stands was also larger than that without stands. As a result, reducibility was improved.

\section{REFERENCES}

1) R. Wild and K. G. Dixton: Agglomeration, ed. by W. A. Knepper, Interscience, New York, (1962), 565.

2) B. Ramberg and S. Eketorp: Jernkont. Ann., 148 (1964), 897.

3) M. Wajima, Y. Hosotani, J. Shibata, H. Sohma and K. Tashiro: Tetsuto-Hagané, 68 (1982), 1719.

4) K. Tashiro, H. Soma, J. Shibata, N. Kon-no and Y. Hosotani: Tetsuto-Hagané, 66 (1980), 1603. 
ISIJ International, Vol. 40 (2000), No. 12

5) K. Nushiro, Y. Konishi, K. Igawa, K. Takihira and N. Fujii: Tetsu-toHagané, 83 (1997), 413.

6) J. Shibata, M. Wajima, H. Soma and H. Matsuoka: Tetsu-to-Hagané, 70 (1984), 178

7) E. Kasai, W. J. Rankin, R. R. Lovel and Y. Omori: ISIJ Int., 29 (1989), 635.

8) T. Inazumi, M. Fujimoto, S. Sato and K. Sato: ISIJ Int., 35 (1995), 372.

9) S. Kasama, T. Inazumi and T. Nakayasu: ISIJ Int., 34 (1994), 562.

10) T. Nakayasu, M. Kobayashi, S. Amano, M. Nakayama, T. Nosaki, T.
Terada, M. Fujimoto and T. Inazumi: CAMP-ISIJ, 5 (1992), 137.

11) S. Sato, T. Kawaguchi, M. Ichidate and M. Yoshinaga: Tetsu-toHagané, 73 (1987), 804.

12) M. J. Cumming and J. A.Thurlby: Ironmaking Steelmaking, 17 (1990), 245.

13) T. Inazumi, M. Fujimoto, S. Amano, S. Matsunaga and T. Nakayasu: CAMP-ISIJ, 7 (1994), 141.

14) K. Nushiro, N. Oyama, K. Igawa and K. Sorimachi: CAMP-ISIJ, 10 (1997), 940. 